\title{
A Bottom-up picture of intra-national welfare regimes: the case of marginalised communities in Puerto Rico
}

\author{
Gibrán Cruz-Martínez (D) ${ }^{\mathrm{a}, \mathrm{b}}$ \\ ${ }^{\mathrm{a} D e p a r t m e n t ~ o f ~ E c o n o m i c s ~ a n d ~ P o l i t i c s, ~ I n s t i t u t e ~ o f ~ P u b l i c ~ G o o d s ~ a n d ~ P o l i c i e s ~(I P P), ~ S p a n i s h ~ N a t i o n a l ~ R e s e a r c h ~}$

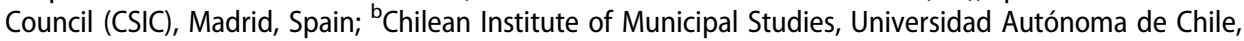 \\ Santiago, Chile
}

\begin{abstract}
The main purpose of this article is twofold: (1) an examination of welfare regimes using a bottom-up approach, which enables a comprehensive analysis of welfare production based on recipients perceptions; and (2) an examination of more than one type of welfare-mix coexisting inside the national level across policy sectors. A classification of welfare regimes is carried out following a bottom-up approach and relying on the basis of the importance of welfare providers to satisfy social risks and promote well-being. Three traditional (e.g. state, market, family) and one alternative welfare providers (e.g. community) are considered. Data is collected through twenty semi-structured interviews in seven marginalised communities of Puerto Rico. The results show five configurations of intra-national welfare-mixes across the following welfare areas: housing, nourishment, health, education, maternity/ paternity, disability, work-unemployment and older-age. This paper contributes to the theoretical proposals of intra-national welfare regimes, and alternatives providers in the welfare-mix.
\end{abstract}

\section{ARTICLE HISTORY}

Received 18 September 2017

Accepted 3 September 2018

\section{KEYWORDS}

Welfare-mix; social risks; welfare state; social policy; Latin America and the Caribbean

\section{Introduction}

Esping-Andersen's (1990) welfare regime theory has been highly praised and criticised in the academia. Scholars working on high-income countries have confirmed the validity of the three welfare regime models (Powell \& Barrientos, 2004), and complemented the tripartite classification (Aspalter, 2006; Mishra, 1994; Yu, Chau, \& Lee, 2015). Regarding the geographic area of interest in this paper, scholars have incorporated Latin America as a model (Barrientos, 2004), and have gone beyond by identifying intra-regional differences in the classification of Latin American welfare regimes (Barba Solano, 2003; Filgueira, 1999; Marcel \& Rivera, 2008; Martínez Franzoni, 2007). Martinez-Franzoni and Sanchez-Ancochea $(2013,2016)$ have examined universalist regimes, highlighting universalism as an achievable policy output in Latin America and the Global South using a combination of coverage, generosity and benefits. However, students of Latin American social policy have concentrated their efforts in examining the national picture of welfare regimes 
following a top-down approach. This raises two limitations in the welfare regime literature, which this paper addresses.

First, the literature draws upon what welfare providers claim to do rather than on what the population reports as actually having access. To solve this limitation, this paper delivers a counterpoint between a traditional top-down approach and a bottom-up approach of Puerto Rico's welfare regime. Especially, analysing the role of traditional welfare providers (e.g. state, market, family) and an alternative welfare provider (e.g. community) in the allocation of resources and distribution of social risks according to the perception of residents in marginalised communities of Puerto Rico. The community is considered as part of a broader 'institutional responsibility matrix' acting as a fourth institutional actor to the state-market-family trinity in producing livelihoods and distributing welfare (Gough, 2013, p. 211). What is the role of the state, market, family and the community in the production of welfare and allocation of social risks in marginalised communities of Puerto Rico? What is the dominant locus of solidarity in the policy areas of housing, nourishment, health, education, maternity/paternity, disability, work-unemployment and older-age?

A second limitation in the scholarship is the scarce literature on intra-national variations of welfare regimes to show territorial dynamics of social policy. Welfare regimes in countries with robust welfare states, such as those examined by Esping-Andersen (1990), report important variations across social policy sectors. Gough (2013, p. 207) made this evident when highlighting that the so-called 'liberal Britain still retains a universal National Health Service'. Ratigan (2017) recently showed a systematic subnational variation with distinct worlds of welfare across Chinese provinces. Based on the experience of marginalised communities, this paper asks if it is possible to identify a social policy fragmentation in Puerto Rico with different intra-national welfare regimes across social policy sectors. Moreover, confirms if national welfare regime patterns might, in reality, be programme-specific.

Income generating strategies of individuals are too diverse and complex to be sufficiently explained by quantitative research methods (Budowski, Tillmann, Keim, \& Amacker, 2010). Moreover, welfare provision and resource allocation strategies in the welfare-mix are complex as well, thus in-depth qualitative approach is required for its understanding. In this paper, data is collected through twenty semi-structured interviews conducted in seven marginalised communities of Puerto Rico. A classification of welfare regimes is carried out following a bottom-up approach and relying on the basis of the importance of welfare providers to satisfy social risks and promote well-being in the eight policy areas considered in this research.

This paper proposes an intra-national welfare regimes theory portraying different welfare-mixes across policy areas. The bottom-up characterisation of Puerto Rico's welfare regime shows different types of welfare-mixes co-existing inside the national level. Residents from marginalised communities evidence five configurations of intranational welfare-mixes across the eight policy sectors mentioned above.

The paper is organised as follows. The next section briefly addresses the theoretical framework with an emphasis on the intra-national welfare regimes and the community as an alternative welfare provider. The research design is presented in the following section, describing the selection of communities, interviewees and the structure of the interviews. The fourth section presents the main research findings (i.e. the bottom-up picture of intranational welfare regimes according to marginalised communities in Puerto Rico). The article finishes with a discussion and a general conclusion. 


\section{Theoretical framework}

During the last three decades, a significant group of scholars has been examining the historical experience and development of Latin American welfare systems and welfare regimes. The welfare systems in Latin America and the Caribbean has been grouped as emerging welfare states (Huber \& Stephens, 2012), welfare states in development (CruzMartinez, 2017b, 2017d), institutional-redistributive welfare states (Sanchez de Dios, 2015), welfare states in transition (Esping-Andersen, 1996), and developmental welfare states in the making (Riesco, 2009), meaning that their welfare programmes and institutions are not yet as developed/institutionalised as their counterparts in Europe. However, these broad classifications do not show the different worlds of welfare across the Latin American region.

Instead of referring to the welfare state, scholars have been using the term welfare regime to depict the distribution of social risks between providers of welfare. According to the pioneer and path-breaking work of Esping-Andersen (1999, pp. 34-35), a welfare regime could be defined as the interdependent way in which the state, market and family (i.e. welfare actors or welfare providers) combine to allocate risks and produce well-being. ${ }^{1}$ And the welfare-mix - another concept that will constantly be used in the following pages - is the articulation of the welfare actors in the welfare production.

Gough (2013), in his own words, 'reconceptualise the welfare regime paradigm developed within Northern social policy studies to understand the nature and diversity of social policies in the South'. Based on previous research with Geoff Wood, he proposes an informal (in)security regime for the Global South as an analogue ideal-type welfare state regime model (Gough \& Wood, 2004; Wood \& Gough, 2006). More recently, three meta-welfare regimes were identified in the Global South: proto-welfare state regimes, informal security regimes and insecurity regimes (Sharkh \& Gough, 2010). ${ }^{2}$ This is one of the multiple frameworks that allow us to consider specificities and commonalities across the Global South without imposing frameworks developed in (and using countries from) the Global North. Barrientos (2004) follows a similar logic to Gough (2013) expanding Esping-Andersen's approach to include Latin America. His main argument is that 'there is enough commonality in welfare provision across Latin American countries to argue that they share a common welfare regime' (2004, p. 122). He argues that the Latin American welfare regime shifted from a conservative-informal to a liberal-informal welfare regime due to changes in economic and social institutions after the Washington Consensus on the origins of the neoliberal era. This liberal shift brought an increased reliance on the market for welfare provision as well as a greater burden on the individual, and a reduction of welfare benefits linked to class and status (i.e. social insurance as an employment protection). Barrientos argues that the lack of a basic safety net (i.e. social protection floor) add-up the 'informal' characterisation to both regime classifications.

\section{Latin American welfare regimes and the need to overcome state-centric and top- down approaches}

Moreover, a similar critique applies to the global south welfare regimes mentioned above: grouping the welfare systems does not make justice to show the intra-regional disparities. Complementing Mesa-Lago's (1989) pioneering work, Filgueira (1999) proposes a welfare 
regime typology showcasing the intra-regional variety of welfare-mixes. His typology results in three regimes. The stratified universalism exhibits a central role of the state, with a relatively high level of social protection coverage (universalism) and a differentiated quality and access to welfare benefits across class (stratified). The main difference between the remaining two regimes is the degree of the population excluded from the welfare programmes, being around half of the population in the dual regimes and the vast majority in the exclusionary regimes (Molina, 2006).

According to Barba Solano (2009) the welfare regime scholarship has generated a consensus portraying the Latin American regime - during the state-led industrialisation era very close to the European conservative regimes although more exclusive (i.e. a difference in the degree of stratification but not on the nature of the welfare regime). Nonetheless, like Filgueira, Barba Solano (2003) finds out three welfare regimes developed under the umbrella of the social security paradigm: the universalist, the dualist and the exclusionary. The differences between the welfare regimes are mainly in the degree of coverage and quality of welfare benefits, rather than in the nature of the welfare programmes.

Huber and Stephens (2005) identify five clusters of social policy regimes in Latin America and the Caribbean. They examined the coverage, magnitude, rules for entitlements and mode of financing of social welfare programmes providing cash transfers and benefits in kind. In line with Barba Solano and Filgueira, the main difference between clusters is the degree of coverage and effort - declining from the first to the fourth. However, the main novelty was the inclusion of English speaking Caribbean countries, which were grouped in the fifth cluster, and alongside Costa Rica - from the first cluster - showed a difference in nature with the first four clusters (i.e. stronger importance on health and education expenditure relative to social security).

More recently, Pribble (2011) identified four social policy regimes ${ }^{3}$ using proxy measures along two dimensions of the coverage of social protection policies [i.e. risk prevention (social investment in education and healthcare) and risk coping (pension coverage of workers in the formal and informal sector). Even though Filgueira, Barba Solano, Pribble, Huber and Stephens identified different welfare regimes in the region, in reality, these portray differences in the degree of coverage, expenditure and welfare outcomes and not necessarily differences in nature. Therefore, the previous researchers have all considered Latin American welfare regime under the Bismarckian welfare tradition. This broad picture helps us understand the generalisations in the welfare provision by the multiple actors in the welfare-mix. However, it does not make justice to present the different worlds of welfare across/inside countries.

Martinez-Franzoni (2008) goes beyond distinguishing countries based on the different degrees of coverage, social expenditure, and welfare outcomes to proof empirically qualitative different roles played by actors in the welfare-mix. Her welfare regimes examined the interaction and allocation of resources between public policy, labour market and family/unpaid work. Following Rudra (2007), Martinez-Franzoni takes into account the role played by public policy in welfare production by promoting access to the market or protecting people from the market. In addition, Martinez-Franzoni also considers Orloff's (1996) arguments on the role of the family in unpaid care-taking provision. Martinez-Franzoni distinguishes three welfare regimes: the state-productivist, where public policy emphasise productivity in the labour market (i.e. emphasis in the commodification of labour work with state-targeted provisions); the state-protectionist, where public policy 
provides welfare mainly via social protection linked to formal employment (i.e. emphasis in the decommodification of welfare with state-stratified provisions); and the non-state familialist, where there is a weak or inexistent role of public policies to provide welfare and thus a high level of dependence on the family (i.e. emphasis in the defamilialisation of welfare with targeted, conditional and basic social assistance programmes).

Martinez-Franzoni overcomes the state-centric limitation by incorporating the role of the family in the unpaid work care-taking. However, the top-down approach still persists in her cutting-edge work. A large part of the literature on welfare regimes in Latin America - and the world - rely on what the state claims to do (i.e. statecentric approach) via social expenditure, coverage and outcomes, what the market and family claims to do, as well as what individuals are entitled. However, this does not inform on what the population reports as actually having access to, and more importantly, it does not describe how each actor provides welfare to individuals. This is why a bottom-up approach is much needed to confirm, deny and/or clarify the valuable messages derived from aggregated national statistical data. The bottomup approach provides a much-needed framework enabling a comprehensive analysis of welfare production based on recipients perceptions.

\section{Role of alternative actors in the welfare-mix}

Multiple actors are involved in the production, consumption and distribution of goods, services and welfare policies. Marcel and Rivera (2008) proposed an alternative-mixed welfare regime typology where two alternative actors (i.e. informality and businesses) join the welfare-mix alongside the three traditional welfare providers (i.e. state, market, family). This novel approach expands the generic concept of the 'market' into three actors. Informality refers to the welfare provided by the wages generated in the informal sector. Firms, on the other hand, provide benefits in kind to their employees as part of the so-called corporate social responsibility, regardless of the wages they pay. Markets then refer to the provision of a salaried job for workers in the formal market.

Marcel and Rivera proposes a typology with nine welfare regimes: social democratic (state is the main provider), proto-welfare state (state shares a complementary role with family, firms or market), liberal (market is the main provider or it shares a complementary role with firms or family), conservative (complementary provision between family and firms), conservative-corporatist (firms are the main provider), conservative-familiarist (family is the main provider), dual (informality shares an exclusionary role with firms or market), informal-destatised (complementary provision between informality and family), and finally the informal regime (informality is the main provider).

When examining the construction process of social citizenship, Filgueira (1998) considers there are still categories and central actors missing from the dominant theories. Marcel and Rivera's framework highlights the importance of evaluating alternative welfare providers. Taking into consideration the population addressed in this research, it is of utmost importance to consider the community as a potential alternative welfare provider. The term community could be defined as a group of people with a common identity and concerns, with social and psychological ties to a delimitated geographical space and its inhabitants (Chanan, 2002; Mattessich \& Monsey, 2004). 
The neoliberal shift in the post-1980s brought a transformation of the state-society relationship and to social policy. 'Through policies of decentralisation, welfare [started to be] provided through seeking cooperation and co-financing from local communities' and other alternative welfare providers (Roberts, 2001, p. 5). The particularity in the case of Puerto Rico is the top-down approach followed by the government to empower communities and promote their role as alternative welfare providers. From the beginning of the XXI century, the Government of Puerto Rico started to rescue ${ }^{4}$ previous efforts to encourage the self-management of marginalised and impoverished communities. The Government also began to train community leaders, and with the statewide Special Communities Programme, it took an official stance to spread the organisational and self-management movement over a large part of Puerto Rico's marginalised communities. ${ }^{5}$

According to Colón Reyes (2003, p. 15), the Special Communities Programme was developed following the social capital theoretical perspective. The vision was to promote economic development while guaranteeing general well-being and social redistribution amongst residents. The Puerto Rican Government promoted social policy innovation through what Evans (1996) labels as complementarity and embeddedness. Both the government and the communities had a common interest in a successful outcome and each actor was able to provide what the other needs but did not had (i.e. complementarity). Embeddedness refers to the relationships of trust between the government and community members bolstering common interest in the policy outcome and thus facilitating complementarity (Roberts, 2001, p. 10).

Even though the welfare regime's literature do not regularly consider the community and other alternative actors as welfare providers, this paper includes this alternative actor in the examination of the welfare-mix, especially because the target population in this research are organised communities with regular assemblies, active participation, self-government and with a clear motivation to promote community development. ${ }^{6}$ The community can participate in the allocation of social risks and welfare production by improving collective well-being and quality of life. ${ }^{7}$ Martínez Franzoni (2008a) recalls Polanyi's (1944) identification of four resource allocations practices by which actors provide welfare to individuals within a welfare-mix: first, following a self-sufficient logic (i.e. communities living exclusively on their production); second, symmetric structures following a gendered-division of labour to allocate resources based on reciprocity within the framework of personal kinship relationships; third, a state-centric structure allocating resources in a top-down approach both in quantity and criteria, based on the logic of collective allocation of resources; fourth, market structures allocating resources from the commercial exchange (i.e. individuals gain access to goods and services in exchange for selling their labour-power).

Examining welfare regimes using a bottom-up approach, and conceptualising welfare regimes as alternative or mixed is not enough to present the reality of resources allocation and welfare production. Traits of more than one ideal welfare regime may coexist within the same country, even though countries could be classified as closer to one specific ideal model. In the same manner that Martinez-Franzoni and Marcel Rivera found intraregional different welfare regimes, it could be possible to find important variations in the welfare production across policy sectors. This paper questions the possibility of identifying different welfare regimes across policy areas. 


\section{Research design}

This research takes Marcel and Rivera alternative framework - but with two modifications - to examine the role of the state, market, family and the community in the welfare-mix of Puerto Rican marginalised communities. First, the market is considered as a trinity in itself (i.e. formal labour market, informal labour market and firms). Even though there is undeniable valuable usefulness of treating each of the 'market' actors separately, the 'market' welfare provider in this research considers the income and benefits generated by any means. Second, the community is included as an alternative welfare provider.

Semi-structured interviews were conducted in marginalised communities to learn how various actors satisfied the basic needs and social risks of residents across eight policy areas. Interviews were kept flexible and dynamic, and the questions were open and customisable, according to the responses provided by the interviewees. The interviewer collected details on specific issues and social risks by creating an informal atmosphere in the conversation - between equals (Taylor \& Bogdan, 1987) - and guided the interview according to the interviewees' responses.

\section{The selection of communities}

All seven communities in the sample are part of the so-called Special Communities Programme. The first law signed by the former Governor Sila Calderon (Act No. 1 of 1 March 2001) was the Law for the Integral Development of the Special Communities of Puerto Rico. This law created the Office for the Special Communities of Puerto Rico (OCEPR for its acronym in Spanish), a welfare institution that was under the executive power of the Office of the Governor. Its primary objective was to promote the residents involvement in the communities and thus encourage self-management and community empowerment.

The OCEPR identified 686 'special communities' with a high level of disadvantages on a set of socioeconomic variables, which means they presented a degree of marginalisation and income poverty compared to other communities in the archipelago. The project defined a special community 'as a geographically delimited area with low-income families and unequal access to the benefits of economic and social development enjoyed by other sectors of the population' (Colón Reyes, 2003, p. 11).

Selecting communities from the Special Communities Programme facilitated the identification of interviewees. Several of these communities remain organised with identified leadership and a community assembly. It was, therefore, more feasible to contact this population, present the research proposal and find those who were willing to take part in the research.

At the time of the fieldwork, the Office of the General Coordinator for Socioeconomic Financing and Self-Management (OFSA for its acronym in Spanish) grouped so-called 'special communities' into seven regions, known as the: Mayagüez/Aguadilla Region, Ponce Region, Metro Region, Central/Eastern Region. Guayama Region, Fajardo Region and North Region (See Figure 1). The research design took into account this division by selecting one community per region. This geographic representation aims to present the reality of various families in marginalised communities from the seven regions identified by OFSA. While these realities can be representative of the general population of the communities, the sample does not allow us to extrapolate the results. 


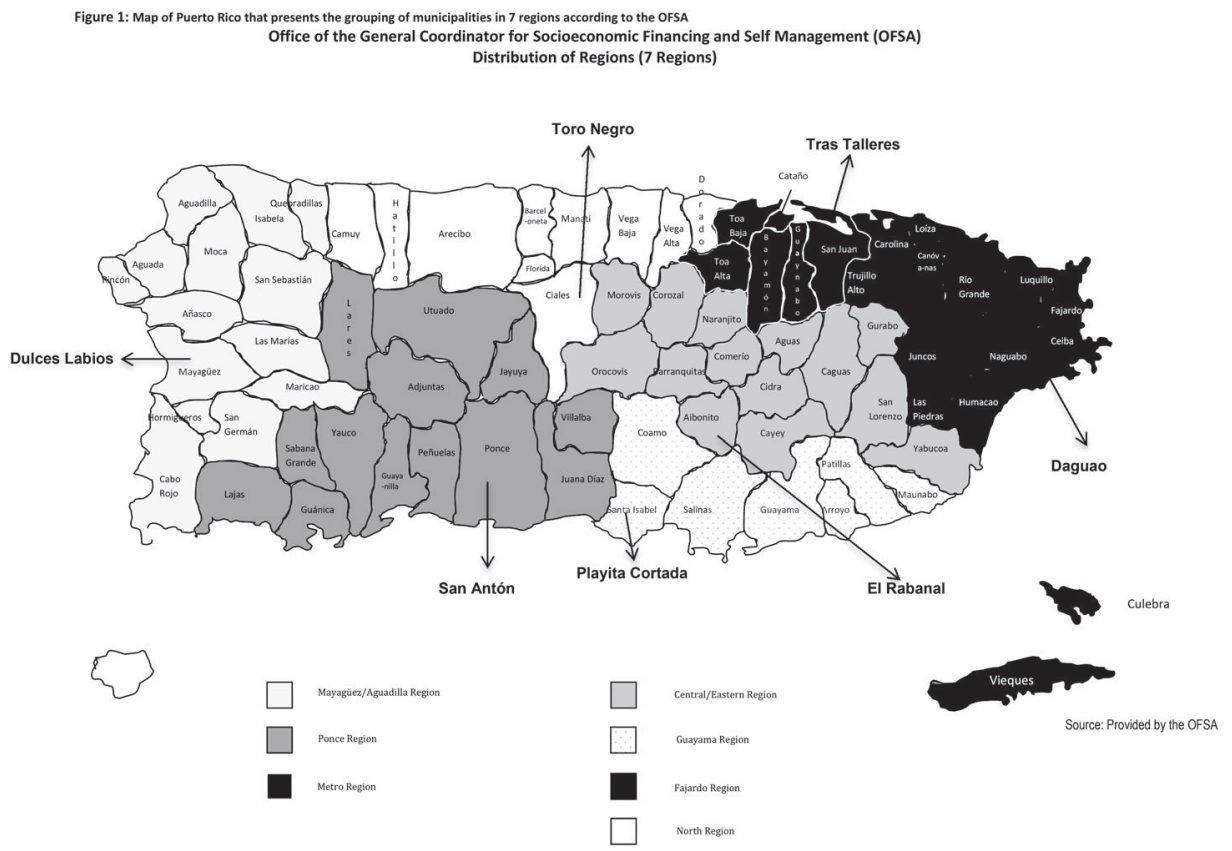

Figure 1. Map of Puerto Rico that presents the grouping of municipalities in 7 regions according to the OFSA. Source: Provided by the OFSA.

Note: Office of the General Coordinator for Socioeconomic Financing and Self Management (OFSA) Distribution of Regions (7 Regions).

Purposeful sampling - a non-probabilistic sampling - was implemented in this research. According to Patton (2002, p. 230):

the logic and power of purposeful sampling lie in selecting information-rich cases for study in depth. Information-rich cases are those from which one can learn a great deal about issues of central importance to the purpose of the inquiry, thus the term purposeful sampling. Studying information-rich cases yields insights and in-depth understanding rather than empirical generalisations.

The selection of the communities for the sample was based on the suggestions of scholars, community activists and the OFSA. In addition to the logic of geographical representation, the level of representativeness in terms of community organisation was also another factor taken into consideration. The final sample includes communities from the seven regions, with varying degrees of self-management and self-sustainability, and with active and inactive assemblies. The following communities were included in the sample:

- Dulces Labios, located in the municipality of Mayagüez and representing the Mayagüez/ Aguadilla region

- San Antón, located in the municipality of Ponce, and representing the Ponce region

- Tras Talleres, located in the municipality of San Juan, and representing the Metro region

- El Rabanal, located in the municipality of Aibonito, and representing the Central/ Eastern region 
- Playita Cortada, located in the municipality of Santa Isabel, and representing the Guayama region

- Daguao, located in the municipality of Naguabo, and representing the Fajardo region

- Toro Negro, located in the municipality of Ciales, and representing the North region

\section{The selection of interviewees}

The sampling of interviewees also followed a purposeful sampling logic. Efforts were made to have a representation of gender (male and female), age range (young, adult and olderage population) and participants with varying degrees of involvement in the community.

The recommendations and expertise of the community leader were taken into account ${ }^{8}$ to identify a balanced group of individuals with the characteristics mentioned above. The leader was advised of the suitability of selecting between two to four cases per community, to have a manageable number of interviews at the end. The first contact with the prospect interviewee was held at the communities, accompanied by the community leader. The research project was then briefly presented to the community resident, and - if interested - a meeting was arranged to conduct the interview at the respondent's preferred time and place. ${ }^{9}$

\section{On the interviews}

A total of twenty interviews were conducted with twenty-three individuals throughout the seven communities. The number of respondents was not the same as the number of interviews because three interviews involved a couple of relatives. The respondents agreed to participate in this unremunerated research, were guaranteed anonymity, and gave their verbal consent beforehand to use the information in future publications. The interviews were conducted in person in six of the seven communities during the research stay in Puerto Rico, while the interviews in the seventh community were agreed in Puerto Rico but conducted overseas by phone. That is, eighteen of twenty interviews were carried out in the respondent's community, specifically in the domicile of the interviewee, a public square, community centre or another community area. The purpose of conducting the interview in the community was to make sure the interviewee felt as comfortable, secure and confident as possible. ${ }^{10}$

The main research questions were: how do the following four welfare providers (state, market, family and community) ensure your well-being and, that of your family, by satisfying your needs and social risks? Which actor do you consider as the main responsible for securing your well-being? These questions were asked on each of the selected areas of welfare. Also, the interviewee was encouraged to elaborate on the aspects that s/he considered appropriate, bearing in mind the main purpose of this research (See Table 1 for a list of guide questions used in the semi-structured interviews).

Housing, maternity/paternity, education, nourishment, health, disability, work-unemployment, and old-age-pension are the welfare dimensions considered in the study. Each of the welfare dimensions were developed with varying depth, depending on the personal circumstances of the interviewee and his/her degree of openness on the different topics. The main welfare provider in every policy area was recorded for each of the interviewees. 
Table 1. Guide questions and social risks and needs being evaluated during the semi-structured interviews.

\begin{tabular}{|c|c|c|}
\hline Welfare area & Question & Social risks and needs being evaluated \\
\hline Housing & $\begin{array}{l}\text { Do you have your own house? } \\
\text { At the time of acquiring your home, how did the } \\
\text { four actors respond to your risks and needs? }\end{array}$ & $\begin{array}{l}\text { Access to a rooftop, income-security to pay } \\
\text { rent/loan, housing in good repair }\end{array}$ \\
\hline Maternity/Paternity & $\begin{array}{l}\text { Do you have children? (If answered negatively, } \\
\text { the following questions are made from the } \\
\text { point of view of a relative in the household.) } \\
\text { At the time of pregnancy, how did the four } \\
\text { actors respond to your risks and needs? } \\
\text { From birth until your children were able to go to } \\
\text { school, how did the four actors respond to } \\
\text { your risks and needs? }\end{array}$ & $\begin{array}{l}\text { Care-taking, nourishment, advise on the } \\
\text { responsibilities and role of parents, maternity/ } \\
\text { paternity leave }\end{array}$ \\
\hline Education & $\begin{array}{l}\text { Do you or your children go to public or private } \\
\text { school? } \\
\text { Do you have schools in the community? If yes, at } \\
\text { what levels? } \\
\text { How did the four actors respond to your (your } \\
\text { children) education-related risks and needs? }\end{array}$ & $\begin{array}{l}\text { Receive a quality education that ensures equal } \\
\text { opportunities, school drop-out, drugs at } \\
\text { school, care of children after school, } \\
\text { availability of resources to pay for university } \\
\text { studies }\end{array}$ \\
\hline Nourishment & $\begin{array}{l}\text { Where do you usually buy your food? } \\
\text { How did the four actors respond to your (your } \\
\text { children) nourishment-related risks and needs? }\end{array}$ & $\begin{array}{l}\text { Food security, nutritious and balanced diet, } \\
\text { food-production at home }\end{array}$ \\
\hline Health & $\begin{array}{l}\text { Do you have health-care coverage? What kind of } \\
\text { health-care coverage, public or private? } \\
\text { At the time of sickness (i.e. needing health-care), } \\
\text { how did the four actors respond to your risks } \\
\text { and needs? } \\
\text { At the time of needing medications, how did the } \\
\text { four actors respond to your risks and needs? }\end{array}$ & $\begin{array}{l}\text { Have medical coverage, economic resources to } \\
\text { face copayments/deductibles in hospitals, } \\
\text { specialists and medicines, care-taking of sick } \\
\text { family members }\end{array}$ \\
\hline $\begin{array}{l}\text { Work- } \\
\text { unemployment }\end{array}$ & $\begin{array}{l}\text { Are you employed? } \\
\text { Are you covered by unemployment insurance? } \\
\text { At the time of unemployment, how did the four } \\
\text { actors respond to your risks and needs? }\end{array}$ & $\begin{array}{l}\text { Income-security, employment, work-related } \\
\text { insurances }\end{array}$ \\
\hline Disability & $\begin{array}{l}\text { Have you or any family member suffered from a } \\
\text { short-term or long-term disability? } \\
\text { If yes, how did the four actors respond to your } \\
\text { (his/her) risks and needs? }\end{array}$ & Income-security, work-related insurances \\
\hline Older-age/pension & $\begin{array}{l}\text { Are you or a member of your family retired? } \\
\text { How did the four actors respond to you or your } \\
\text { family older-age related risks and needs? } \\
\text { Did you pay contributions to the national social } \\
\text { insurance programme? Are you eligible for a } \\
\text { pension? } \\
\text { Does your workplace provide (contributes) a } \\
\text { (towards a) private retirement scheme? }\end{array}$ & $\begin{array}{l}\text { Income-security, care-taking, mobility to attend } \\
\text { medical appointments, go to supermarkets, } \\
\text { and visit family/friends, leisure time }\end{array}$ \\
\hline
\end{tabular}

Note: Elaborated by the author.

The actor considered by the majority of interviewees as the main welfare provider is labelled as the dominant welfare provider. At the end of the interview, respondents completed a brief questionnaire to draft a sociodemographic and socioeconomic profile (see the Appendix for a brief aggregated summary of these characteristics).

\section{Research findings}

Residents in marginalised communities of Puerto Rico considered the family, state and the market as the dominant welfare providers. The market was perceived as the dominant actor in the areas of housing, nourishment and health, while the state was the dominant actor in the areas of education, disability, work-unemployment and older-age. Finally, the 
family was considered the dominant welfare provider, allocating resources in the areas of housing and maternity/paternity.

Table 2 shows a bottom-up picture of the perceived worlds of welfare in eight policy areas. The table does not indicate frequency or intensity, instead it maps the mix of actors considered by the sample of 23 interviewees as the main welfare providers in each of the policy areas. There is an ' $\mathrm{X}$ ' to show the variety of perceived main welfare providers in each policy area. For example, at least one interviewee considered the state and the family as the main welfare providers in the maternity/paternity area. However, none of the interviewees considered the market or the community as the main welfare providers in the maternity/paternity area. The dominant welfare providers are underlined and in bold (i.e. those that were mentioned the most number of times as the main welfare provider). Following the previous example, the family was considered the dominant welfare provider in the maternity/paternity policy area, even though a smaller number of interviewees considered other actors as their main providers (e.g. state, state + family, family + community).

Marcel and Rivera (2008, pp. 172-173) argue that it is common to have multiple welfare providers in highly stratified societies; however when two or more actors coexist in the same policy area it is relevant to distinguish if they are doing so in a complementary or exclusive manner. There is an ' $\mathrm{E}$ ' or ' $\mathrm{C}$ ' in Table 2 when two or more actors are considered as the main welfare providers (E refers to exclusionary actors and $\mathrm{C}$ to complementary actors). For example, in the nourishment area some interviewees considered both, the state and the market, as their main welfare providers. The state and the market complemented each other to satisfy a specific interviewee's social risks. On the contrary, in the education policy area the state and market had an exclusionary role as welfare providers (i.e. the state and market did not work together to satisfy an interviewee's social risks). The remaining part of this section explores the results shown in Table 2 and proposes a classification of intra-national welfare regimes.

\section{A bottom-up picture of the welfare-mix}

The market and the family were considered the dominant welfare providers in the housing dimension, allocating resources through wages received in remunerated employment (market) and the inheritance of houses (family). The following quote describes the role played by both actors according to the perception of an interviewee:

[the house] was made of wood, it was from an aunt of my husband and cousins, who built it on my husband's land. (...) he (husband) bought it from his aunt and his cousins, I do not know if it was in 2 thousand dollars, the wood, because in fact, the land was his. So we fixed it, we conditioned it, and we started living there (...) then we started to rebuild it with concrete, (...) it has been almost 12 or 13 years since we rebuilt it with concrete and it is ours with a lot of effort, with great care, with a lot of tenacity $(. ..){ }^{11}$

The state was perceived as a subsidiary actor useful when it provided subsidies to repair and/or rebuild houses. A respondent supports this by adding, 'Working, definitively. And partly because they gave my mom some government's benefits like material, in the beginning, to build it.' Residents in one of the communities proposed a project to relocate several families who were living in a slum. According to an interviewee, the mayor 
Table 2. A bottom-up welfare-mix: Map of actors perceived as the main welfare providers for the interviewees.

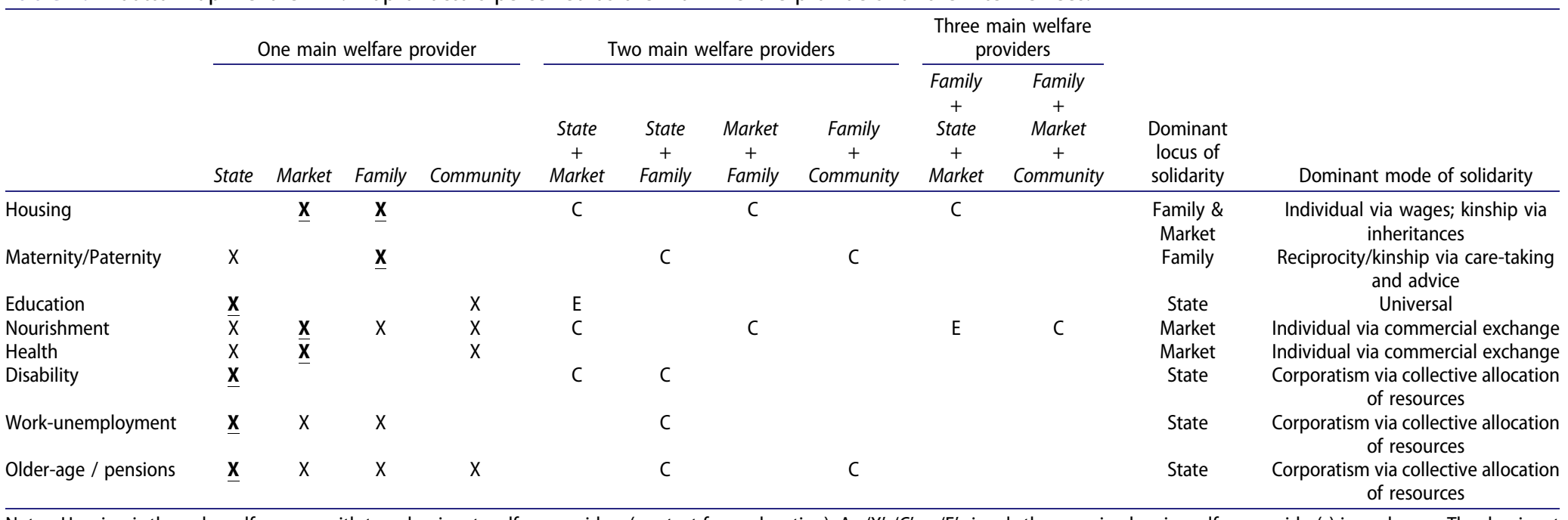

Notes: Housing is the only welfare area with two dominant welfare providers (see text for explanation). An ' $X$ ', ' $C$ ' or ' $E$ ' signals the perceived main welfare provider(s) in each area. The dominant welfare provider is underlined and bold. ' $C$ ' refers to a complementary provision among actors and ' $E$ ' an exclusionary provision among actors. Elaborated by the author. 
intervened and paralysed the relocation project from the slum towards apartments because of partisan political intentions.

Residents considered the family as the dominant welfare provider in the maternity/ paternity dimension. It addressed social risks and satisfied needs associated with pregnancy, as well as risks arising in the early age of newborns by providing care and guidance. The second main actor was the state, which ensured the well-being of some interviewees through targeted and conditional welfare programmes, providing health care and nutrition advice to mothers and infants, as well as daycare in the infant early years. The exclusionary role of the state becomes evident when a resident considers her family as the main welfare provider 'because as I worked, I did not qualify for government benefits'. The community plays a complementary role with the state. One interviewee highlights how the community manages an 'Early Head Start so that single mothers and workers have where to [go] to take care of their children'. The community applied for government funds and is now running an early child care centre for children who meet targeted eligibility criteria.

All interviewees studied in public schools - at least - part of their education. 'Yes, everyone studied in public schools a bit far away, but around here', a respondent confirms. Therefore, the state was perceived as the dominant provider in this dimension. It guaranteed the well-being by providing free and universal public education between the ages of 4-18 years. The market collaborates with the state to secure specific risks not covered by the targeted welfare programmes. The market was perceived as an exclusionary actor, satisfying the risks to infants aged $0-4$ from families with earnings above the income poverty line or who do not qualify to the public infant care programme (i.e. Early Head Start and Head Start). The market also satisfied risks by providing private higher education. Although not considered as a dominant welfare provider, many interviewees mentioned family as an actor present in the welfare-mix providing care to infants while their parents finished their daily work. Most of the communities visited have community centres, which provide students with a place to do their homework, access the internet, access books or encyclopedias and in some cases print for a fixed cost. The Special Communities Project provided computers initially, but they were not renewed at the end of its operational lifetime.

'Well, there were crops of rice, beans, corn, pigeon peas, (...), there was everything. And now to get all those things you have to go to the supermarket.'

The previous quote is one of the multiple portraying the market as the dominant welfare provider in the dimension of nourishment. Interviewees face risks associated with this dimension through wages earned in salaried formal and informal jobs. The state participated in the welfare-mix providing income through social security (for the older-age population) or the Nutritional Assistance Programme. ${ }^{12}$ A resident remarked she buys food at the supermarket.

'Now, [the money I spend comes from] my pension, my years of work and from the social security.'

The family is still portrayed as an important actor although it has lost a starring role in the nourishment dimension because fewer agricultural products are now harvested in the gardens of their domiciles. One of the communities was starting to experiment with a 
community garden, which shortly could provide residents with organic products at a low cost, and at the same time finance the community project (i.e. following a self-sufficient resources allocation logic). At the time of the visit, they were about to collect the first plantain harvest, and they were experimenting with potatoes, culantro, avocado and other minor fruits.

In the health dimension, the market was perceived as the dominant welfare provider. The social risks associated with this dimension were secured primarily by private health insurances funded by the interviewees' salaries. When asked about the way they satisfy their healthcare needs, an interviewee pointed out: 'Usually it's been with private healthcare, I've almost never had the public [healthcare]. Again, normally everyone in my family work (emphasising with the finger).' The state was perceived as the second main welfare provider in this dimension by guaranteeing sick days for employees, and healthcare provision for individuals with income below the income poverty line. This explains why there was a portion of the population without healthcare coverage (i.e. respondents with income above the poverty line have healthcare coverage if they can afford it in the market). The family was again perceived as a provider of care for the sick. Community development in one of the communities visited has allowed them to provide subsidised health care. A medical doctor goes to the community, acting as a general practitioner. The community assumes the copayment as a social responsibility for those considered as 'indigent'.

The state was perceived as the dominant welfare provider in the disability dimension. Although many of the interviewees do not have any disability, they presumed the state's disability programme (SINOT by its Spanish acronym,) would guarantee their well-being if they become disabled in the future. A respondent in a rural community describes the role of the state to allocate resources in this area.

At least I'm not disabled, my husband is, unfortunately. I say unfortunately because he likes to work, he likes to provide, he does not like to stand still. At this time, he has no option, unfortunately, because he has herniated discs, and a sciatic nerve injury (...) he had to apply for social security income through the [State Disability] Fund (...) We spent almost three years fighting to get it. You know, that was an injustice because then if there is a condition, there are some 'records'; you know it was frustrating to see your partner, crawling, bending.

As in the health area, the family was considered a welfare provider satisfying risks through family care.

The dominant actor in the work-unemployment dimension is the state. According to most of those interviewed, income security provided by the unemployment benefits was the main source of well-being related to this dimension. However, according to the interviewees, the cash benefits from these programmes were not working correctly. Two individuals mentioned they were not able to receive cash benefits when unemployed - even though they contributed on a monthly basis - because the former employer did not paid his part of the contributions, and thus they did not appear in the state-registry of the unemployment institution. The family was considered the second main provider, satisfying needs by giving financial assistance to unemployed relatives. The market was regarded as a possible welfare provider by the self-employed, through individual financial provisions and savings. This was the only area where a group of interviewees mentioned that none of the actors allocated resources to face unemployment-related risks.

The state was also perceived as the dominant welfare provider in the old-age dimension. Many of the interviewees mentioned the social insurance pension is - or will be - the main 
source of income security. 'I only have about 5 years left to receive social security' an interviewee claims. He goes on saying that the

social security will be my main economic means, although, for a few years, the company I worked for had a retirement plan, it was like an 'incentive' (...) [to provide additional income] for the employees and also to make them feel part of the company. But it turns out that due to bad luck, the company I worked for was sold, (...) after a few years, 5 or 6 years, the new owner said (...) that [the retirement plan] was incompatible so we were given the money back.

Meanwhile, former state employees considered state pensions as their main source of wellbeing. The family was also part of the welfare-mix providing care and income-transfers to older-age relatives. The market was present in some cases with individual economic provisions, such as savings, investment plans or long-term savings. The community was also active in this area. A group of community leaders was working on a proposal to transform the actual commercial use given to a room in the communal centre, to a day-centre where older-age residents could access food, care and leisure.

The interviews ended with a personal evaluation of the satisfaction towards the role played by each of the four actors in the welfare-mix. The maximum possible score was 10, which meant the actor satisfied all the interviewee's social risks, and zero, which implied it did not meet any social risks. According to the respondents, the state received an average score of 3.92 , the market 5.22, the community 5.33, and the family 8.38 . This result shows the family as the most valued welfare provider and the state as the worst valued.

\section{A classification of the intra-national welfare regimes}

Table 3 shows the welfare regime classification in each policy area using the methodology proposed by Marcel and Rivera (2008). The initial classification takes into account only the dominant welfare provider, and the final classification rectifies the picture by considering the distances in respect with secondary welfare providers and the degree of complementarity.

Results show intra-national variations of welfare regimes across policy areas. The market and the family played a central role in the distribution of social risks associated with the housing area (i.e. evidencing a liberal welfare regime). The market played a central role in the nourishment and health area. However, the state intervenes with a residual role using targeted social assistance programmes. This is why the initial classification of liberal welfare regime for the nourishment and health area is rectified as liberalresidual. The family played a central role in the Maternity/Paternity welfare area, with a care-taking role (i.e. showing a conservative-familialist welfare regime).

The state had a dominant role in the remaining four areas: education, disability, workunemployment, and older-age. In the education area, the provision was universal and free in the elementary, intermediate and high school. Meanwhile, in the other three areas the corporatist role of the state was evident as only those working in the formal sector and meeting the eligibility requirements related to contributions were able to become beneficiaries of disability, pension and unemployment programmes. Even though there is active participation of the state in various welfare areas, public welfare policies cannot be 
Table 3. A bottom-up welfare-mix: Classification of intra-national welfare regimes and the role of welfare providers in the welfare-mix.

\begin{tabular}{|c|c|c|c|c|c|c|c|c|}
\hline & $\begin{array}{l}\text { Welfare regime typology } \\
\text { - initial classification }\end{array}$ & $\begin{array}{l}\text { Welfare regime typology } \\
\text { - final classification }\end{array}$ & $\begin{array}{l}\text { Role of the } \\
\text { State }\end{array}$ & $\begin{array}{l}\text { Role of the } \\
\text { Market }\end{array}$ & $\begin{array}{l}\text { Role of the } \\
\text { Family }\end{array}$ & $\begin{array}{l}\text { Role of the } \\
\text { Community }\end{array}$ & $\begin{array}{l}\text { Decommodification of } \\
\text { welfare }\end{array}$ & $\begin{array}{c}\text { Defamilialisation of } \\
\text { welfare }\end{array}$ \\
\hline Housing & Liberal & Liberal & Marginal & Central & Central & Marginal & Minimal & Minimal \\
\hline $\begin{array}{l}\text { Maternity/ } \\
\text { Paternity }\end{array}$ & Conservative-familialist & Conservative-familialist & $\begin{array}{l}\text { Subsidiary } \\
\text { (for } \\
\text { income- } \\
\text { poor) }\end{array}$ & Marginal & Central & Subsidiary & Low & Minimal \\
\hline Education & Social democratic & Proto-social democratic & Central & Marginal & Marginal & Subsidiary & High & High \\
\hline Nourishment & Liberal & Liberal-Residual & $\begin{array}{l}\text { Subsidiary } \\
\text { (for } \\
\text { income- } \\
\text { poor) }\end{array}$ & Central & Subsidiary & Subsidiary & Minimal & Low \\
\hline Health & Liberal & Liberal-Residual & $\begin{array}{l}\text { Subsidiary } \\
\text { (for } \\
\text { income- } \\
\text { poor) }\end{array}$ & Central & Subsidiary & Subsidiary & Minimal & Low \\
\hline Disability & Social democratic & Corporatist & Central & Marginal & Subsidiary & Marginal & $\begin{array}{l}\text { High (for workers in the } \\
\text { formal market) }\end{array}$ & Low \\
\hline $\begin{array}{l}\text { Work- } \\
\text { unemployment }\end{array}$ & Social democratic & Corporatist & Central & Marginal & Subsidiary & Marginal & $\begin{array}{l}\text { High (for workers in the } \\
\text { formal market) }\end{array}$ & Low \\
\hline $\begin{array}{l}\text { Older-age / } \\
\text { pensions }\end{array}$ & Social democratic & Corporatist & Central & Marginal & Subsidiary & Marginal & $\begin{array}{l}\text { High (for workers in the } \\
\text { formal market) }\end{array}$ & Low \\
\hline
\end{tabular}

Notes: We can speak of the de-familialisation of welfare when the social risks are fulfilled by reducing the dependence that exists in the family to ensure the individual's well-being. When social risks are satisfied by lowering market dependency, then we can speak of the de-commodification of welfare (Esping-Andersen, 1999). According to Marshall (1950), the process of decommodification weakens the economic linkage between welfare and participation in the labour market. When the state has a major role in ensuring the population's well-being, then we can speak of a state-centric welfare regime (i.e. corporatist and proto-social democratic) while a regime that targets welfare to a specific population is considered a residual welfare regime (i.e. liberal residual welfare regime).

Elaborated by the author. 
considered as promoting equality of the highest standards, but rather equality of minimal needs (Esping-Andersen, 1990, p. 112; Hernes, 1987). This is the main reason to consider welfare regimes in the state-dominant areas as proto-social democrats rather than social democratic (i.e. not to be confused with the social democratic Nordic welfare states). Therefore, a modified welfare regime typology is proposed in Table 3: a liberal welfare regime in the area of housing, a liberal-residual regime in the nourishment and health areas, a conservative-familialist regime in the maternity/paternity area, a corporatist regime in the disability, work-unemployment and older-age area, and a proto-social democratic regime in the education area. In the areas of housing, nourishment, health and - to a lesser degree - maternity/paternity there is a high level of commodification (for individuals with income above the poverty line) with public residualism (for persons with income below the poverty threshold). This creates a dualism between residents with earnings above the poverty line - who usually satisfy social risks in these areas through the market - and residents with earnings below the poverty line - who typically satisfy social risks in these areas through the targeted and highly stigmatised social assistance programmes. There is a high degree of familialism in the four areas. In the areas of maternity/paternity and housing, the family plays the dominant role in the allocation of social risks and production of well-being. The family is also present in the areas of nourishment and health through the provision of care and income transfers.

In the areas of disability, unemployment and old age, this research found a high degree of state-centrism, a marginal role of the market, with a subsidiary role of the family. This again creates a dualism of benefits between residents working in the formal sector - who contribute monthly to the welfare institutions and thus can become beneficiaries of disability, unemployment and old age welfare programmes - and residents working in the informal sector who does not have access to contributory welfare programmes (i.e. rights are attached to class and status). Social risks that are associated with education have a high degree of state-centrism, with the highest degree of decommodification and defamilialisation of welfare in the policy areas examined.

\section{Discussion and conclusion}

Even though it is possible to identify the main actors allocating resources and providing welfare, residents confirmed they go to a multiplicity of actors in all eight welfare areas. The bottom-up picture shows a complex and diverse welfare-mix, difficult to simplify in one national ideal welfare regime. This section briefly discusses three issues derived from the previous section: the difference between the top-down versus bottom-up approach to present the Puerto Rican welfare regime, the role played by alternative welfare actors to allocate resources in the welfare-mix, and the need to address the intra-national variations of welfare regimes across policy areas.

It is difficult to frame Puerto Rico's welfare regime as state-productivist, state-protectionist or any other regime addressed in the Latin American welfare regime scholarship. The Latin American country has been excluded from most - if not all - typologies. However, using Esping-Andersen (1990) typology as a reference and following a topdown approach, the Puerto Rican welfare regime could be seen as a liberal-residual one.

Puerto Rico's welfare system shares a significant similarity with the United States' welfare state (Cruz-Martinez, 2017c; Morrissey, 2006). This is expected because Puerto 
Rico is one of the colonial possessions of the United States of America (See Ayala \& Bernabe, 2009; Caban, 2002; Cruz-Martinez, 2017a; Developments in the Law, 2017; González-Cruz, 1998; Pantojas, 2005). 'Political and economic dependency on the United States [of America] has had a significant impact on the development of the [Puerto Rican] welfare system' (Seda, 1990, p. 202). Colón Reyes (2002, p. 27), notes that 'public assistance policies in Puerto Rico are determined economically, socially and politically by federal [United States of America] policies'. A large part of the institutions and welfare programmes in the archipelago are administered and/ or funded partly by the United States of America. However, Puerto Rican's residual welfare state has its peculiarities, institutions and agendas, and faces a different social, political and economic reality than its metropolis. Working in the shadows of both Latin America and the United States of America, Puerto Rico shares from both the high degree of stratification stemming from income inequality in the most unequal region in the world and the most unequal country of the high-income economies.

Therefore, a top-down approach would portray Puerto Rico following the United States' ideal regime (i.e. the modal example of the liberal-residual welfare regime). In this kind of regime, individuals need to ensure their well-being through the market (liberal), and only those 'incapable' of accessing private welfare programmes are granted targeted and/or conditional social assistance programmes (residual). Nonetheless, an institutionalised social insurance programme is embedded in the Puerto Rican welfare regime providing coverage to individuals working in the formal sector.

Barrientos' and Gough's welfare regimes have been criticised for the 'overgeneralization that positions all Latin American countries together under one single welfare regime' (Martínez Franzoni, 2008b, p. 71). In the same manner, a new critical reflection is needed because of another overgeneralisation in the welfare regime literature. A large part of the literature considers that one ideal welfare regime is enough to portray the diverse and complex process of resources' allocation among welfare providers, and the various way individuals - from different social classes and neighbourhoods inside a national boundary - go to a varied mix of welfare providers to satisfy their social risks.

The interconnected and complex welfare-mix seen in the bottom-up approach followed in this paper does not display one single welfare regime in Puerto Rico. On the contrary, there is a variety of actors in the welfare-mix of each welfare dimension; each one providing welfare and allocating resources through different means, modes and combinations. Specifically, the bottom-up approach shows five welfare regimes perceived by residents in the marginalised communities of Puerto Rico (see Table 3).

The bifurcation model that Skocpol (1988) attached to the United States social policy is also confirmed in the perception of residents in Puerto Rican marginalised communities. With the massive expansion of US assistance policies and institutions to the archipelago after the 1970s crisis and the US 'War on Poverty', a bifurcation process of the Puerto Rican social policy began to flourish. On the one hand, social security programmes (e.g. unemployment benefits, disability benefits and pensions) are guaranteed for workers in the formal sector. These social security programmes are conceptualised as 'legitimate' and 'earned' welfare programmes. On the other hand, targeted and means-tested social assistance programmes (e.g. nutritional assistance programme, public health care 'Mi Salud') are available only for residents meeting the income poverty criteria. Interviewees 
depict recipients of these social assistance programmes as 'lazy', 'dependent' and/or incapable of satisfying their social needs by their owns means in the labour market.

Interviewees portrayed the community as an alternative actor - main or complementary - providing welfare in five of the eight welfare areas. It may not be producing wellbeing via orthodox social policy (i.e. social insurance and social assistance programmes), but its role as an alternative actor providing 'social policy by other means' should not be overlooked. For example, (1) in the organisation and provision of communal spaces for medical care, (2) by subsidising the medical care costs for residents in extreme income poverty in exchange for community work, (3) by creating and maintaining educational spaces where students can access books and a computer with internet, (4) by establishing and maintaining community vegetable gardens to provide residents with organic products at a low cost and at the same time fund the community project. Also, most of the interviewees considered that their well-being and quality of life has improved since the community has been organising and practising self-management. The interviews showed the positive impact of the community actor in the improvement of the quality of life of the population in the following areas: drug abuse problems, education about civic responsibility, agriculture, recreation, economic development, health and infrastructure.

The intra-national welfare regimes theory portraying different welfare-mixes across policy areas needs to be explored further with a more significant sample of residents and of marginalised communities, as well as the inclusion of other sectors of society. Interesting will be to confirm if we are able to distinguish different welfare regimes not only across policy sectors but also across social classes inside the national boundary. Future research could also further examine the role played by alternative welfare actors in the intra-national welfare regimes of Puerto Rico and other Latin American countries, as well as include the other two main variables in the welfare regime scholarship (i.e. welfare outcomes and social stratification) to the one considered in this paper (i.e. the role of the welfare actors).

\section{Notes}

1. The state, family and market are traditional actors that provide one or more rationales for the production and allocation of resources. There are multiple papers in the welfare regime literature conceptualising the state, market and family as 'actors' in the welfare-mix (Heuer, Leruth, Mau, \& Zimmermann, 2016; Longo et al., 2015; Marcel \& Rivera, 2008). 'Welfare actors' and 'welfare providers' are used interchangeably in this paper.

2. The main difference among regimes resides in its welfare outcomes and the dominant locus of solidarity. Proto-welfare state regimes have the highest outcomes, and the dominant welfare provider is the state. Informal security regimes have intermediate outcomes and individuals go to the community and family to meet their needs. The insecurity regimes have the lowest welfare outcomes and there are not even stable informal security mechanisms.

3. The 'mobilizing incorporation-industrialist', the 'corporatist incorporation-industrialist', the 'interrupted incorporation-agrarian', and the 'exclusionary-agrarian' social policy regimes.

4. For example, the movement to organise and develop marginalised communities in the mid$\mathrm{XX}$ century through the education sector (DIVEDCO), the group of land takeovers as a bottom-up distribution of land, as well as the Programme of self-help and self-effort ('Programa de Ayuda Mutua y Esfuerzo Propio'). 
5. See Ribas and Ghoshal (2013) for a better understanding of how the Puerto Rican state 'simultaneously help give rise to [the community] social movements and shape the emergent oppositional consciousness of movement leaders' (p. 404).

6. Community development is

a process of developing and enhancing the ability to act collectively and an outcome: (1) taking collective action and (2) the result of that action for improvement in a community in any or all realms: physical, environmental, cultural, social, political, economic, etc. (Phillips and Pittman, 2009, p. 6)

7. See Lee, Kim, and Phillips (2015) for a theoretical discussion on community well-being, community development and societal well-being.

8. The selection method of the interviewees in the Toro Negro community followed another logic. I (i.e., the interviewer) presented the research project to the community at a community assembly, and as a result, three residents volunteered to be interviewed.

9. The research design considered the accompaniment of the community leader during the first visit as a way to build trust and empathy with the potential interviewees.

10. The interviews were carried out between 27 March and 21 July 2013.

11. The author translated this and the remaining quotes from Spanish to English.

12. Known in the United States of America as 'food stamps'.

\section{Acknowledgements}

The fieldwork was conducted while the author was a Visiting Fellow at the Centro de Investigaciones Sociales, University of Puerto Rico. Previous versions of this paper were written while the author was a Postdoctoral Research Fellow at the University of Agder, and a Visiting Fellow at the Latin American Centre, University of Oxford. I would like to thank Manuel Domenech, Manuel Sánchez de Dios, Mayrin García, Laura Ortiz, Annie Fabián, Doris Pizarro, Víctor Vázquez, Norma Rodríguez, Centro para Puerto Rico, Francisco Pesante the Institute of Statistics of Puerto Rico, and the anonymous reviewers who provided data, references and/or much appreciated comments on the field or on earlier drafts of this article. Shortcomings, of course, remain my responsibility.

\section{Disclosure statement}

No potential conflict of interest was reported by the author.

\section{Funding}

This paper is in part possible by funding of the Spanish Ministry of Education, Culture and Sport (Ministerio de Educación, Cultura y Deporte) (FPU 2009-0069).

\section{Notes on contributor}

Gibrán Cruz-Martínez is a Juan de la Cierva Postdoctoral Researcher at the Institute of Public Goods and Policies, Spanish National Research Council (CSIC). Before joining IPP-CSIC, he was affiliated to the University of Agder (Norway), and the Institute of the Americas, University College London (United Kingdom). He holds a PhD in Political Science from the Universidad Complutense (Spain). His work broadly speaking focuses on the development of emerging welfare states in Latin America and the Caribbean and its relationship to multidimensional poverty and inequality. In addition, his research interests include welfare regimes and social risks in marginalised communities, targeting versus universalism in social protection, and basic universal social pensions in low- and middle-income countries. His most recent publication is an open 
access book entitled 'Produciendo Bienestar: Una mirada desde las comunidades marginadas en Puerto Rico' (Dykinson, 2017). He has been a visiting researcher or fellow at the University of Oxford (United Kingdom), Lund University (Sweden), Centre for Social Research (Puerto Rico), the Comparative Research Programme on Poverty at the University of Bergen (Norway), and the Institute of Latin American Studies at the University of London (United Kingdom). He is also a member of the Editorial Board of Alternautas - an open access blog and Journal on Latin American critical development studies.

\section{ORCID}

Gibrán Cruz-Martínez (D) http://orcid.org/0000-0002-4583-2914

\section{References}

Aspalter, C. (2006). The East Asian welfare model. International Journal of Social Welfare, 15(4), 290-301. doi:10.1111/j.1468-2397.2006.00413.x

Ayala, C. J., \& Bernabe, R. (2009). Puerto Rico in the American Century: A history since 1898. Chapel Hill: University of North Carolina Press.

Barba Solano, C. (2003). El nuevo paradigma de bienestar residual y deslocalizado. Reforma de los regímenes de bienestar en la OCDE, América Latina y México (PhD Social Science). Universidad de Guadalajara, México.

Barba Solano, C. (2009). Los regímenes de bienestar latinoamericanos y la reforma social. In C. Barba Solano, G. Ordoñez Barba, \& E. Valencia Lomelí (Eds.), Más allá de la pobreza: Regímenes de bienestar en Europa, Asia y América (pp. 327-370). Guadalajara: Universidad de Guadalajara, El Colegio de la Frontera Norte.

Barrientos, A. (2004). Latin America: Towards a liberal-informal welfare regime. In I. Gough, \& G. Wood (Eds.), Insecurity and welfare regimes in Asia, Africa and Latin America: Social policy in development contexts (pp. 121-168). Cambridge: Cambridge University press.

Budowski, M., Tillmann, R., Keim, W., \& Amacker, M. (2010). Conceptualizing 'precarious prosperity': Empirical and theoretical elements for debate. International Journal of Comparative Sociology, 51(4), 268-288. doi:10.1177/0020715210368840

Caban, P. A. (2002). Puerto Rico: State formation in a colonial context. Caribbean Studies, 30(2), $170-215$.

Chanan, G. (2002). Community development foundation measure of community: A study for the active community unit and research. London: Development and Statistics Unit of the Home Office.

Colón Reyes, L. (2002). Neoliberalismo, Globalización y Pobreza en Puerto Rico. In F. E. Martínez, \& F. A. Catalá (Eds.), Ensayos sobre la pobreza en Puerto Rico (pp. 19-53). Puerto Rico: Publicaciones Puertorriqueñas / Unidad de Investigaciones Económicas.

Colón Reyes, L. (2003). El Pais Posible: Modelo de Apoderamiento y Autogestión para las Comunidades Especiales de Puerto Rico. San Juan: Oficina para el Financiemiento Socioeconómico y la Autogestión.

Cruz-Martinez, G. (2017a). The end of colonialism in Puerto Rico? Evaluating the options in the 2017 political status referendum. LSE LAC Blog. Retrieved from http://blogs.lse.ac.uk/ latamcaribbean/2017/05/05/the-end-of-colonialism-in-puerto-rico-evaluating-the-options-inthe-2017-political-status-referendum/

Cruz-Martinez, G. (2017b). Is there a common path that could have conditioned the degree of welfare state development in Latin America and the Caribbean? Bulletin of Latin American Research, 36(4), 459-476. doi:10.1111/blar.12556

Cruz-Martinez, G. (2017c). Produciendo Bienestar. Una mirada desde las Comunidades Marginadas en Puerto Rico. Madrid: Dykinson.

Cruz-Martinez, G. (2017d). Welfare state development, individual deprivations and income inequality: A cross-country analysis in Latin America and the Caribbean. Social Indicators Research, 134(3), 955-979. doi:10.1007/s11205-016-1465-4 
Developments in the Law. (2017). The U.S. Territories - The international place of Puerto Rico. Harvard Law Review, 130(6), 1616-1656.

Esping-Andersen, G. (1990). The three worlds of welfare capitalism. Princeton, NJ: Princeton University Press.

Esping-Andersen, G. (1996). Welfare states in transition: National adaptations in global economy. London: Sage.

Esping-Andersen, G. (1999). Social foundations of post industrial economies. New York, NY: Oxford University Press.

Evans, P. (1996). Government action, social capital and development: Reviewing the evidence on synergy. World Development, 24(6), 1119-1132.

Filgueira, F. (1998). El nuevo modelo de prestaciones sociales en América Latina: residualismo, eficiencia y ciudadanía estratificada. In R. Brian (Ed.), Ciudadanía y Política Sociales (pp. 71116). San José de Costa Rica: FLACSO/SSRC.

Filgueira, F. (1999). Tipos de Welfare y reformas sociales en América Latina: Eficiencia, residualismo y ciudadanía estratificada. In M. Melo (Ed.), Reforma do Estado e Mudanca Institucional no Brasil (pp. 123-158). Recife: Fundacao Joaquim Nabuco.

González-Cruz, M. (1998). The U.S. Invasion of Puerto Rico. Latin American Perspectives, 25(5), 7 26. doi:10.1177/0094582x9802500502

Gough, I. (2013). Social policy regimes in the developing world. In P. Kennett (Ed.), A handbook of comparative social policy (pp. 205-224). Cheltenham: Edward Elgar.

Gough, I., \& Wood, G. (2004). Insecurity and welfare regimes in Asia, Africa and Latin America. Cambridge: Cambridge University Press.

Hernes, H. (1987). Welfare state and woman power. Oslo: Norwegian University Press.

Heuer, J. O., Leruth, B., Mau, S., \& Zimmermann, K. (2016). Attitudes towards the welfare mix: How citizens in Germany and the United Kingdom attribute responsibilities for social welfare to state, market, and family - and why? Paper for the 2016 Annual ESPAnet Conference, 1-3 September 2016, Erasmus University Rotterdam, The Netherlands.

Huber, E., \& Stephens, J. (2005, October 7-8). Successful Social Policy Regimes? Political Economy, Politics, and the Structure of Social Policy in Argentina, Chile, Uruguay, and Costa Rica. Paper prepared for the Conference on Democratic Governability Kellogg Institute, University of Notre Dame.

Huber, E., \& Stephens, J. D. (2012). Democracy and the left. Social policy and inequality in Latin America. Chicago: The University of Chicago Press.

Lee, S. J., Kim, Y., \& Phillips, R. (2015). Community well-being and community development. Conceptions and applications. Switzerland: Springer.

Longo, F., Notarnicola, E., \& Tasselli, S. (2015). A framework to assess welfare mix and service provision models in health care and social welfare: Case studies of two prominent Italian regions. BMC Health Services Research, 15, 152. doi:10.1186/s12913-015-0800-9

Marcel, M., \& Rivera, E. (2008). Regímenes de bienestar en América Latina. In E. Tironi (Ed.), Redes, Estado y Mercado. Soportes de la Cohesión Social Latinoamericana (pp. 151-226). Santiago de Chile: Uqbar editores.

Marshall, TH. (1950). Citizenship and social class and other Essays. Cambridge: Cambridge University Press.

Martínez Franzoni, J. (2007). Regímenes del bienestar en América Latina. Documento de Trabajo, 11, Fundación Carolina-CeALCI. Retrieved from http://www.fundacioncarolina.es/es-ES/ publicaciones/documentostrabajo/Documents/DT11.pdf

Martínez Franzoni, J. ((2008a)). Arañando bienestar? Trabajo remunerado, protección social y familias en America Central. Buenos Aires: CLACSO / CROP.

Martínez Franzoni, J. (2008b). Welfare regimes in Latin America: Capturing constellations of markets, families, and policies. Latin American Politics and Society, 50(2), 67-100.

Martínez Franzoni, J. (2008). Welfare regimes in Latin America: Capturing Constellations of Markets, Families, and Policies. Latin American Politics and Society, 50(2), 67-100.

Martinez-Franzoni, J., \& Sanchez-Ancochea, D. (2013). Can Latin American production regimes complement universalistic welfare regimes?: Implications from the Costa Rican case. Latin American Research Review, 48(2), 148-173. 
Martinez-Franzoni, J., \& Sanchez-Ancochea, D. (2016). The quest for universal social policy in the south: Actors, ideas and architectures. Cambridge: Cambridge University Press.

Mattessich, P., \& Monsey, M. (2004). Community building: What makes it work. St Paul, MN: Wilder Foundation.

Mesa-Lago, C. (1989). Ascent to bankruptcy: Financing social security in Latin America. Pittsburgh: University of Pittsburgh Press.

Mishra, R. (1994). Typologies of the welfare state and comparative analysis: The "liberal" welfare state. Journal of International and Comparative Social Welfare, 10(2), 90-106. doi:10.1080/ 17486839408414907

Molina, C. G. (2006). Universalismo básico: Una nueva política social para América Latina. Washington, DC: Banco Interamericano de Desarrollo / Editorial Planeta.

Morrissey, M. (2006). The making of a colonial welfare state. Latin American Perspectives, 33(1), 23-41. doi:10.2307/27647904

Orloff, A. (1996). Gender in the welfare state. Annual Review of Sociology, 22, 51-78.

Pantojas, G. E. (2005). The Puerto Rican paradox: Colonialism revisited. Latin American Research Review, 40(3), 163-176.

Patton, M. Q. (2002). Qualitative research and evaluation methods. Thousand Oaks, CA: Sage.

Phillips, R., \& Pittman, R. (2009). Introduction to community development. London: Routledge.

Polanyi, K. (1944). The great transformation. New York, NY: Rinehart.

Powell, M., \& Barrientos, A. (2004). Welfare regimes and the welfare mix. European Journal of Political Research, 43(1), 83-105.

Pribble, J. (2011). Worlds apart: Social policy regimes in Latin America. Studies in Comparative International Development, 46(2), 191-216. doi.org/10.1007/s12116-010-9076-6

Ratigan, K. (2017). Disaggregating the developing welfare state: Provincial social policy regimes in China. World Development, 98, 467-484. doi:10.1016/j.worlddev.2017.05.010

Ribas, V., \& Ghoshal, R. A. (2013). States make movements? The material and discursive influence of state-sponsored community organizing in Puerto Rico. Sociological Perspectives, 56(3), 403437. doi:10.1525/sop.2013.56.3.403

Riesco, M. (2009). Latin America: A new developmental welfare state model in the making? International Journal of Social Welfare, 18, S22-S36. doi:10.1111/j.1468-2397.2009.00643.x

Roberts, B. R. (2001). The new social policies in Latin America and the development of citizenship: An interface perspective.. Paper for Workshop on Agency, Knowledge and Power: New Directions, Wageningen, 14th-15th December.

Rudra, N. (2007). Welfare states in developing countries: Unique or universal? The Journal of Politics, 69(2), 378-396.

Sanchez de Dios, M. (2015). La reforma de los regímenes de bienestar en Costa Rica, Chile, Argentina, Brasil y Uruguay. Política y Sociedad, 52(3), 661-690. doi:10.5209/rev_POSO.2015. v52.n3.45377

Seda, R. M. (1990). Puerto Rico. In J. Dixon, \& R. P. Scheurell (Eds.), Social welfare in Latin America (pp. 202-248). New York, NY: Routledge.

Sharkh, M. A., \& Gough, I. (2010). Global welfare regimes. Global Social Policy: An Interdisciplinary Journal of Public Policy and Social Development, 10(1), 27-58. doi:10.1177/1468018109355035

Skocpol, T. (1988). The limits of the new deal system and the roots of contemporary welfare dilemmas. In M. Weir, A. S. Orloff, \& T. Skocpol (Eds.), The politics of social policy in the United States (pp. 293-312). Princeton, NJ: Princeton University Press.

Taylor, S. J., \& Bogdan, R. (1987). La entrevista en profundidad Introducción a los métodos cualitativos de investigación: La busqueda de significados (pp. 100-132). Barcelona: Editorial Paidós Iberica S.A.

Wood, G., \& Gough, I. (2006). A comparative welfare regime approach to global social policy. World Development, 34(10), 1696-1712.

Yu, S., Chau, C. M., \& Lee, K. M. (2015). Using defamilisation typologies to study the Confucian welfare regime. Journal of International and Comparative Social Policy, 31(1), 74-93. doi:10. $1080 / 21699763.2014 .992457$ 
Appendix. Aggregated socio-economic and socio-demographic characteristics of interviewees

\begin{tabular}{|c|c|c|c|c|c|c|c|c|c|c|c|}
\hline \multicolumn{12}{|l|}{ Age range } \\
\hline & $0-17$ & $18-24$ & $25-34$ & $35-44$ & $45-54$ & $55-64$ & $65-74$ & $75-84$ & $85+$ & $\begin{array}{c}\text { DK/NA (Don't } \\
\text { Know/No } \\
\text { Answer) }\end{array}$ & Total \\
\hline & 0 & 0 & 1 & 4 & 4 & 3 & 4 & 2 & 0 & 2 & 20 \\
\hline \multicolumn{12}{|l|}{ Gender } \\
\hline & Woman & Man & Other & DK/NA & & & & & & & \\
\hline & 8 & 10 & 0 & 2 & & & & & & & \\
\hline \multicolumn{12}{|c|}{ Marital status } \\
\hline & Married & Single & Widowed & Divorced & Consensual union & Separated & DK/NA & Total & & & \\
\hline & 9 & 5 & 0 & 1 & 2 & 1 & 2 & 20 & & & \\
\hline \multicolumn{12}{|l|}{ Schooling } \\
\hline & Preschool & Elementary & Intermediate & High-School & $\begin{array}{c}\text { Associate degree } \\
\text { (occupational or } \\
\text { technical } \\
\text { programme) }\end{array}$ & Bachelor degree & No schooling & DK/NA & Total & & \\
\hline & 1 & 0 & 2 & 3 & 7 & 4 & 1 & 2 & 20 & & \\
\hline \multicolumn{12}{|c|}{ Employment status } \\
\hline & Full time & Part-time & Unemployed & $\begin{array}{l}\text { Out of the labour } \\
\text { force }\end{array}$ & Homemaker & $\begin{array}{l}\text { Retired with } \\
\text { social security }\end{array}$ & $\begin{array}{l}\text { Retired with } \\
\text { pension }\end{array}$ & $\begin{array}{l}\text { Disability } \\
\text { with social } \\
\text { security }\end{array}$ & Student & DK/NA & Total \\
\hline & 5 & 2 & 0 & 3 & 1 & 2 & 3 & 2 & 0 & 2 & 20 \\
\hline \multicolumn{12}{|c|}{ Monthly personal income (US dollars) } \\
\hline & $1-499$ & $500-999$ & $1000-1499$ & $1500-1999$ & $2000-2499$ & +2500 & DK/NA & Total & & & \\
\hline & 1 & 4 & 4 & 5 & 2 & 2 & 2 & 20 & & & \\
\hline \multicolumn{12}{|c|}{ Monthly household income (US dollars) } \\
\hline & $1-499$ & $500-999$ & $1000-1499$ & 1500-1999 & $2000-2499$ & +2500 & DK/NA & Total & & & \\
\hline & 1 & 2 & 6 & 3 & 0 & 5 & 3 & 20 & & & \\
\hline \multicolumn{12}{|c|}{ Welfare benefits of the interviewee $\left(^{*}\right)$} \\
\hline & $\begin{array}{c}\text { Public } \\
\text { healthcare }\end{array}$ & $\begin{array}{l}\text { Financial Aid } \\
\text { Programme }\end{array}$ & $\begin{array}{c}\text { Electricity } \\
\text { Payment Subsidy }\end{array}$ & $\begin{array}{c}\text { Nutritional } \\
\text { Assistance } \\
\text { Programme (PAN) }\end{array}$ & $\begin{array}{l}\text { Supplemental } \\
\text { Nutrition } \\
\text { Programme for } \\
\text { Women, Infants, } \\
\text { and Children (WIC) }\end{array}$ & Medicaid & Scholarship & $\begin{array}{l}\text { Social } \\
\text { Security }\end{array}$ & $\begin{array}{l}\text { Telephone } \\
\text { Payment } \\
\text { Subsidy }\end{array}$ & None & DK/NA \\
\hline & 6 & 1 & 0 & 0 & 0 & 2 & 0 & 7 & 0 & 6 & 3 \\
\hline
\end{tabular}


Housing Conditions

House and land House and land owner tenant

18

Infrastructure problems of the house $(*$

Roof and walls House needs

have water

repair

leaks

(n)

$\begin{array}{cc}4 & 4 \\ \text { None } & \text { DK/NA } \\ 5 & 7\end{array}$

Problems in the community $(*)$

Illegal dumps Lack of

and junkyards recreational and
sports facilities

6

Flooding area 7
Shortage of

schools

Social problems (*)

Drug abuse Unemployment

ack of school Mental illnesses transportation
Homeowner on Homeowner Half of the land with government's without title deed title deed, another land

0 half without title
Electrical wiring is old or
damaged frequently
Water pipes are old or damaged
frequently$$
4
$$
Not enough
bedrooms

2

Housing in poor Empty dwellings

condition (public nuisances)

$$
\stackrel{9}{9}
$$

$$
6
$$

4
Poor security
Agglomeration of houses and people$$
7
$$

4

0

Air pollution

Need of sewers

$\begin{array}{ccccc}\begin{array}{c}\text { Vacant land: } \\ \text { Need of } \\ \text { housing }\end{array} & \begin{array}{c}\text { Noise } \\ \text { pollution }\end{array} & \begin{array}{c}\text { Road in poor } \\ \text { conditions }\end{array} & \begin{array}{c}\text { Houses are } \\ \text { prone to } \\ \text { landslide }\end{array} & \begin{array}{c}\text { Water } \\ \text { pollution }\end{array} \\ 4 & 4 & 5 & 0 & 3\end{array}$

Inadequate or
non-existent

$\begin{array}{cc}\text { Teenage } & \text { School } \\ \text { pregnancy } & \text { dropouts }\end{array}$

Alcohol

Juvenile Vandalism public transportation

abuse

Delinquency

Prostitution

$\begin{array}{cc}7 & 6 \\ \text { Sexual abuse } & \text { Older-age } \\ \text { / rape } & \text { abuse }\end{array}$

K/NA

$$
2
$$

3

1

0

0

3

groups

4

Notes: The number refers to the number of times each item was marked/considered. Interviewees could mark more than one option in the four questions with the asterisk (*). In interviews with a couple of relatives, only one interviewee completed the questionnaire. Results are displayed in aggregated form to comply with the anonymity agreement and avoid the identification of any interviewee. 